\title{
KERAGAAN PERTUMBUHAN DAN WARNA IKAN WILD BETTA (Betta sp.) DENGAN REKAYASA INTENSITAS CAHAYA DAN WARNA LATAR
}

\author{
Riani Rahmawati ${ }^{\#}$, Sawung Cindelaras, dan Eni Kusrini
}

Balai Penelitian dan Pengembangan Budidaya Ikan Hias

\begin{abstract}
ABSTRAK
Penelitian ini dilakukan untuk menguji pengaruh kondisi lingkungan dengan intensitas cahaya dan warna latar yang berbeda terhadap pertumbuhan dan warna ikan cupang (Betta sp.). Biota uji diberi kombinasi perlakuan perbedaan kondisi cahaya dan warna latar, yaitu: (A-1) 100 lux dan latar putih; (A-2) 100 lux dan latar hitam; (A-3) 100 lux dan latar biru; (B-1) 800 lux dan latar putih; (B-2) 800 lux dan latar hitam; (B-3) 800 lux dan latar biru; (C-1) 1.500 lux dan latar putih; (C-2) 1.500 lux dan latar hitam; dan (C-3) 1.500 Lux dan latar biru. Setiap perlakuan diulang tiga kali. Ikan diberikan pakan berupa larva Chironomus sp. secara ad libitum. Penelitian dilakukan selama 84 hari. Hasil terbaik diperoleh pada perlakuan A-1 (intensitas 100 lux dan latar putih), dengan laju pertumbuhan spesifik panjang dan bobot masing-masing sebesar 0,48 \pm $0,06 \%$ hari dan $0,75 \pm 0,22 \%$ hari; sintasan sebesar $100 \%$ serta persentase perubahan hue (H), saturation (S), dan brightness (B) berturut-turut adalah $21 \pm 18,6 \pm 10$, dan $6 \pm 18$.
\end{abstract}

KATA KUNCl: intensitas cahaya; warna latar; pertumbuhan; wild betta

ABSTRACT: Growth dan colour performance of wild betta fish (Betta sp.) with Manipulation of light intensity and background colour. By: Riani Rahmawati, Sawung Cindelaras, and Eni Kusrini

\begin{abstract}
This research was conducted to deter mine the effect of rearing environment and light intensity with different background coloration to improve the color quality and growth of wild betta fish (Betta sp.). The fishs which were placed in the small tanks and treated with different light intensities and background coloration. The treatments combinations were: (A-1) 100 lux and white background, (A-2) 100 lux and black background, (A-3) 100 lux and blue background, (B-1) 800 lux and white background, (B-2) 800 lux and black background, (B-3) 800 lux and black background, (C-1) 1,500 lux and white background, (C-2) 1,500 lux and black background, and (C-3) 1,500 lux and blue background. Each treatment was repeated threetimes. The fish were fed onfrozen Chironomus larvae twice a day. The research was conducted for 84 days. The result showed that the combination of 100 lux and white background resulted the best growth rate $(0.48 \pm 0.06 \mathrm{~cm} /$ day in length and $0.75 \pm 0.22 \%$ day in weight) and survival rate of $100 \%$ The best combination had the value of hue $(21 \pm 18)$, saturation $(6 \pm 10)$, and brightness $(6 \pm 18)$.
\end{abstract}

\section{KEYWORDS: light intensity; background colour; growth; wild betta}

\section{PENDAHULUAN}

Indonesia merupakan daerah endemik penyebaran ikan cupang alam (wild betta) terbesar di dunia. Ikan cupang alam terbagi menjadi 13 kelompok spesies ditinjau dari karakter morfologinya (Tan, 2011; Goldstein, 2004). Kualitas ikan hias ditinjau dari segi warna dan juga pertumbuhan yang baik. Keragaman dan keunikan warna yang ditampilkan dari suatu produk merupakan karakter komersial penting yang dapat memengaruhi tingkat penerimaan konsumen terhadap suatu produk hewani, sehingga turut menentukan nilai

\footnotetext{
\# Korespondensi: Balai Penelitian dan Pengembangan Budidaya Ikan Hias. Jl. Perikanan No. 13, Pancoran Mas, Depok 16436 , Jawa Barat, Indonesia. Tel.: + (021) 7520482 E-mail: riani_38@yahoo.co.id
}

jual produk tersebut di pasar (Colihueque, 2010; Tume et al., 2009). Perubahan warna biasanya terjadi hanya pada kecerahan dan keburamannya saja yang disebabkan adanya perubahan jumlah sel pigmen. Perubahan sel pigmen, terutama melanin, dipengaruhi atau dikontrol oleh hormon pituitari dan adrenalin (yang disekresikan dari otak). Ikan yang dipelihara pada lingkungan yang mendapat cahaya terang akan memberikan reaksi warna yang berbeda dengan ikan yang dipelihara di tempat gelap karena adanya perbedaan reaksi melanosom yang mengandung pigmen melanofor terhadap rangsangan cahaya yang ada (Said et al., 2005). Woods (2000) mengemukakan bahwa pertumbuhan dan sintasan $\mathrm{H}$. abdominalis dipengaruhi oleh warna latar. Warna latar merupakan faktor lingkungan yang paling dominan dalam 
mengendalikan perubahan pigmentasi kulit pada beberapa ikan (van der Salm et al., 2004).

Perubahan faktor lingkungan seperti lama penyinaran dan suhu juga dapat memengaruhi pertumbuhan dan perkembangan organisme (Elseth \& Baumgardner, 1984 dalam Said \& Tanjung, 1997). Menurut Han et al. (2005), intensitas cahaya dapat memengaruhi pertumbuhan secara nyata dan intensitas cahaya yang optimal untuk Leiocassislongirostris Günther sebesar 312 lux. Warna ikan Leiocassis longirostris Günther menjadi lebih gelap di bawah cahaya dengan intensitas 434 lux. Munculnya warna akan stabil dan lebih jelas pada saat ikan berukuran lebih besar. Ikan berukuran kecil pada umumnya belum terlihat karakteristik warna yang jelas, sehingga peningkatan pertumbuhan yang semakin cepat, dapat mempermudah dalam seleksi ikan berdasarkan warnanya. Oleh karena itu, penelitian ini bertujuan untuk mengevaluasi pengaruh kondisi lingkungan dengan intensitas cahaya dan latar yang berbeda terhadap pertumbuhan dan warna ikan cupang (Betta sp.).

\section{BAHAN DAN METODE}

Penelitian dilakukan di Panti Pembenihan Cupang, Balai Penelitian dan Pengembangan Budidaya Ikan Hias, Depok. Biota uji yang digunakan adalah ikan wild betta (Betta sp.) dengan panjang 2,4 $\pm 0,2 \mathrm{~cm}$ dan bobot $0,29 \pm 0,03 \mathrm{~g}$. Ikan dipelihara dalam wadah kecil berukuran $20 \mathrm{~cm} \times 10 \mathrm{~cm} \times 20 \mathrm{~cm}$ yang diletakkan dalam akuarium besar berukuran $80 \mathrm{~cm} \times 50 \mathrm{~cm} \times$ $50 \mathrm{~cm}$ yang diberikan air menggenang (water bath) untuk menstabilkan suhu, dan dipasang heater dalam wadah pemeliharaan pada suhu $28^{\circ} \mathrm{C}$. Wadah kecil berjumlah 27 buah yang ditempatkan dalam tiga akuarium besar, sehingga setiap akuarium besar diisi wadah kecil sebanyak sembilan buah (Gambar 1). Setiap wadah diisi tiga ekor ikan cupang (Betta sp.) sebagai ulangan individu.

Kombinasi perlakuan yang diterapkan dengan perbedaan intensitas cahaya dan warna latar sesuai dengan Tabel 1. Setiap kombinasi perlakuan diulang sebanyak tiga kali. Pakan yang diberikan berupa larva Chironomus sp. secara ad libitum dengan frekuensi pemberian pakan dua kali sehari.

Ikan difoto, kemudian panjangnya diukur menggunakan kamera Canon SLR EOS 600 D yang kemudian dianalisis dengan software "ImageJ" untuk mendapatkan data pengukuran berdasarkan perbandingan dengan skala ukur (menggunakan kertas millimeter block). Untuk mengetahui pertambahan bobot badan ikan, penimbangan dilakukan menggunakan timbangan CHQ DJ302BH ketelitian 300 $\mathrm{g} / 0,01 \mathrm{~g}$. Penelitian dilakukan selama 84 hari dan setiap tiga minggu sekali dilakukan pengukuran panjang dan bobot.

Penilaian perubahan warna dihitung dengan cara membandingkan warna badan ikan uji bagian lateral dengan salah satu warna yang terdapat Toca Colour Finder (TCF). Dalam penelitian ini standar pembanding warna yang digunakan yaitu warna green dengan kode TC-4005. Ikan uji difoto dalam sarana pemotretan (Gambar 2) dengan jarak pengambilan foto dan penerangan yang sama selama sampling. Hasil pemotretan diolah dan dianalisis ke dalam bentuk hue $(H)$, saturation (S), dan brightness (B) menggunakan software "adobe photoshop CS3 portable". Kisaran nilai HSB untuk hue $(H)$ sebesar $0-360$, saturation $(S)$ sebesar 0-100 dan brightness (B) sebesar 0-100 (Gambar 1).

Tabel 1. Perlakuan rekayasa intensitas cahaya dan warna latar selama penelitian

Table 1. Manipulation of light intensity and background colour treatment during experiment

\begin{tabular}{cc}
\hline \multicolumn{2}{c}{ Perlakuan (Treatments) } \\
\hline $\begin{array}{c}\text { Intensitas cahaya } \\
\text { Light intensity (lux) }\end{array}$ & $\begin{array}{c}\text { Warna latar } \\
\text { Background colour }\end{array}$ \\
\hline 100 & Putih (White) \\
100 & Hitam (Black) \\
100 & Biru (Blue) \\
\hline 800 & Putih (White) \\
800 & Hitam (Black) \\
800 & Biru (Blue) \\
\hline 1,500 & Putih (White) \\
1,500 & Hitam (Black) \\
1,500 & Biru (Blue) \\
\hline
\end{tabular}



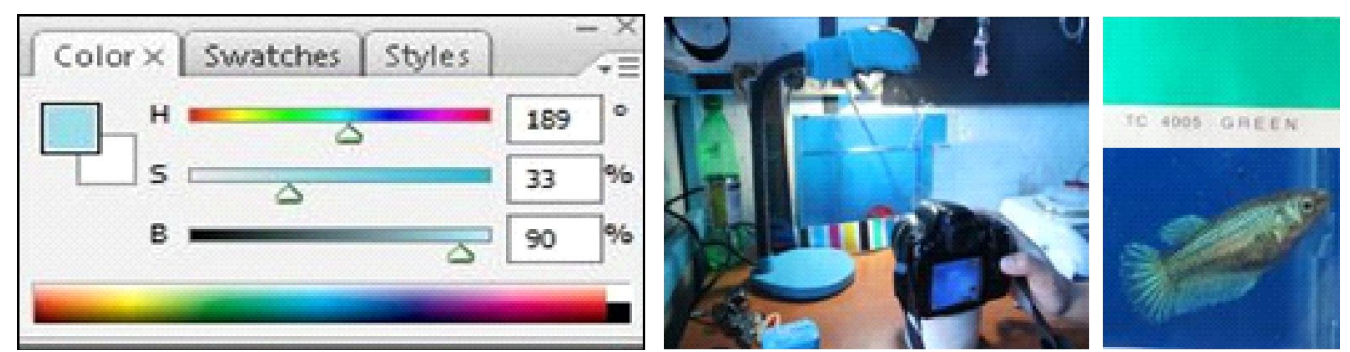

Gambar 1. Wadah pemeliharaan dan proyeksi penentuan nilai analisa warna ikan dalam HSB

Figure 1. Rearing tank and projection valuation analysis of fish colour on HSB

Laju pertumbuhan spesifik panjang, bobot, dan sintasan yang diperoleh dianalisis secara statistik sedangkan perubahan warna tubuh ikan dianalisis secara tabulasi dan deskriptif. Penelitian ini menggunakan rancangan acak kelompok. Analisis statistik dilakukan dengan menggunakan software IBM SPSS statistics 20.

Laju pertumbuhan harian spesifik dihitung berdasarkan rumus (Corazani, 1997):

$$
\mathrm{SGR}=\frac{\mathrm{LnWt}-\mathrm{LnW}}{\mathrm{t}} \times 100
$$

di mana:

SGR: laju pertumbuhan harian (\%hari)

Wt : bobot rata-rata individu akhir penelitian

Wo : bobot rata-rata awal penelitian

t : lama penelitian (hari)

Sintasan adalah persentase jumlah ikan yang hidup pada akhir pengamatan dibandingkan jumlah ikan pada awal pemeliharaan. Sintasan dihitung berdasar rumus:

$$
\text { Sintasan }(\%)=\frac{N t}{N_{0}} \times 100 \%
$$

di mana:

$\mathrm{Nt} \mathrm{:} \mathrm{jumlah} \mathrm{ikan} \mathrm{awal} \mathrm{pemeliharaan} \mathrm{(ekor)}$

No : jumlah ikan akhir pemeliharaan (ekor)

Hubungan antara intensitas cahaya dan perubahan warna tubuh ikan uji menggunakan analisis regresi. Data disajikan dalam bentuk gambar (grafik) dan tabel.

Parameter utama yang diamati dalam penelitian ini adalah perubahan warna, pertumbuhan panjang, dan bobot, serta sintasan, sedangkan parameter penunjang yang diamati adalah kualitas air selama penelitian. Parameter kualitas air yang diamati meliputi $\mathrm{pH}$, oksigen terlarut, $\mathrm{CO}_{2}$, alkalinitas, $\mathrm{NH}_{3}$, $\mathrm{NO}_{2}$, dan hardness.

\section{HASIL DAN BAHASAN}

Tabel 2 menunjukkan bahwa dari analisis statistik lanjutan, perlakuan kombinasi antara intensitas cahaya dan warna latar yang berbeda memberikan pengaruh yang nyata terhadap laju pertumbuhan spesifik panjang dan bobot $(P<0,05)$, namun tidak berpengaruh nyata terhadap sintasan $(P>0,05)$. Ikan yang diberikan perlakuan dengan latar putih dan intensitas cahaya 100 lux menunjukkan pertumbuhan panjang yang paling tinggi $(0,48 \pm 0,06 \%$ hari $)$ dibandingkan dengan perlakuan lainnya.

\section{Laju Pertumbuhan Spesifik (SGR) dan Sintasan}

Laju pertumbuhan spesifik panjang menunjukkan beda nyata $(P>0,05)$ antar perlakuan intensitas cahaya 100 lux dan latar putih dengan perlakuan intensitas cahaya 100 (latar hitam), intensitas cahaya 800 lux (latar hitam) dan intensitas cahaya 1.500 lux (latar biru) (Tabel 2). Intensitas cahaya 100 lux dengan latar putih sangat baik dalam meningkatkan pertumbuhan panjang ikan uji. Hal ini dipengaruhi oleh pemangsaan pakan pada latar putih lebih terlihat oleh ikan uji, sehingga pakan lebih mudah tertangkap oleh ikan uji. Hal ini sesuai dengan pernyataan Henne \& Watanabe (2003); Jentoft et al. (2006); Strand et al. (2007), bahwa tingkat pertumbuhan ikan lebih tinggi pada tangki putih daripada tangki hitam $(P<0,05)$. Konsumsi pakan juga meningkat di bawah kondisi cahaya rendah dan latar yang terang. Konsumsi pakan yang lebih tinggi terlihat dari pertumbuhannya yang lebih baik dibanding perlakuan lainnya, hal ini diakibatkan dari peningkatan visibilitas terhadap pakan, diduga karena pakan terlihat lebih kontras terhadap warna latar tangki. Wadah dengan latar putih meningkatkan tingkat pemangsaan dan konsumsi pakan. Ini mengindikasikan bahwa latar putih sangat menarik larva dan memengaruhi perilaku makan (efek kaca).

Habitat ikan cupang di alam yaitu pada lahan gambut dengan kondisi cahaya yang rendah. Pada kondisi intensitas cahaya cahaya rendah (100 lux) ikan menjadi lebih tenang dan tidak stres. Di samping itu, dengan kombinasi warna latar putih akan membuat pakan lebih jelas terlihat dalam kondisi cahaya rendah, sehingga pakan lebih mudah tertangkap dan nafsu makan ikan lebih baik dalam kondisi sesuai habitatnya 
Tabel 2. Laju pertumbuhan panjang dan bobot serta sintasan pada setiap perlakuan kombinasi Table 2. Length and weight growth rate and survival rate in each combination treatment

\begin{tabular}{|c|c|c|c|c|c|}
\hline \multicolumn{2}{|c|}{ Perlakuan (Treatments) } & \multirow{2}{*}{\multicolumn{2}{|c|}{$\begin{array}{l}\text { Laju pertumbuhan } \\
\text { spesifik panjang (\%/hari) } \\
\text { Spesific growth rate } \\
\text { of length (\%day) }\end{array}$}} & \multirow{2}{*}{$\begin{array}{l}\text { Laju pertumbuhan } \\
\text { spesifik bobot (\%/hari) } \\
\text { Spesific growth rate } \\
\text { of weight (\%day) }\end{array}$} & \multirow{2}{*}{$\begin{array}{c}\text { Sintasan } \\
\text { Survival rate } \\
\text { (\%) }\end{array}$} \\
\hline $\begin{array}{l}\text { Intensitas } \\
\text { Intensity (lux) }\end{array}$ & $\begin{array}{l}\text { Warna latar } \\
\text { Background }\end{array}$ & & & & \\
\hline \multirow{3}{*}{100} & Putih (White) & Al & $0.48 \pm 0.06^{c}$ & $0.75 \pm 0.22^{\mathrm{ab}}$ & $100^{\mathrm{a}}$ \\
\hline & Hitam (Black) & $\mathrm{A} 2$ & $0.23 \pm 0.11^{\mathrm{ab}}$ & $0.85 \pm 0.08^{\mathrm{ab}}$ & $100^{\mathrm{a}}$ \\
\hline & Biru (Blue) & A3 & $0.33 \pm 0.10^{\mathrm{abc}}$ & $1.01 \pm 0.23^{\mathrm{ab}}$ & $100^{\mathrm{a}}$ \\
\hline \multirow{3}{*}{800} & Putih (White) & B1 & $0.27 \pm 0.13^{\mathrm{abc}}$ & $0.63 \pm 0.18^{\mathrm{a}}$ & $100^{\mathrm{a}}$ \\
\hline & Hitam (Black) & B2 & $0.18 \pm 0.02^{\mathrm{a}}$ & $0.76 \pm 0.09^{\mathrm{ab}}$ & $100^{\mathrm{a}}$ \\
\hline & Biru (Blue) & B3 & $0.44 \pm 0.06^{\mathrm{bc}}$ & $1.11 \pm 0.04^{b}$ & $100^{\mathrm{a}}$ \\
\hline \multirow{3}{*}{1,500} & Putih (White) & $\mathrm{Cl}$ & $0.28 \pm 0.11^{\mathrm{abc}}$ & $0.94 \pm 0.12^{\mathrm{ab}}$ & $100^{\mathrm{a}}$ \\
\hline & Hitam (Black) & $\mathrm{C} 2$ & $0.26 \pm 0.06^{\mathrm{abc}}$ & $0.67 \pm 0.23^{\mathrm{ab}}$ & $100^{\mathrm{a}}$ \\
\hline & Biru (Blue) & C3 & $0.16 \pm 0.06^{\mathrm{a}}$ & $0.79 \pm 0.09^{\mathrm{ab}}$ & $100^{\mathrm{a}}$ \\
\hline
\end{tabular}

(cahaya rendah). Hal tersebut diduga mendukung pertumbuhan yang optimal. M enurut Mills et al. (1986), secara umum tingkat pertumbuhan tertinggi larvaikan dicapai bila kondisi cahaya dan warna latar optimal, kontras antara pakan dan latar belakang. Lebih lanjut menurut Mairesse et al. (2005); Strand et al. (2007), warna tangki dan intensitas cahaya adalah faktor penting untuk dipertimbangkan dalam rangka untuk memaksimalkan asupan pakan dan tingkat pertumbuhan juvenil Perca fluviatilis L., sehingga pada tingkat yang optimal dapat meningkatkan produksi budidaya ikan ini.

Korelasi pertumbuhan panjang mutlak dengan warna latar mengikuti persamaan polinomial. Berdasarkan nilai korelasi, hubungan pertumbuhan bobot mutlak dengan warna latar (nilai $R^{2}=0,4796$ ) lebih baik jika dibandingkan pertumbuhan panjang mutlak dengan intensitas cahaya (nilai $R^{2}=0,2176$ ) (Gambar 2). Hal ini menunjukkan bahwa perbedaan warna latar lebih memengaruhi pertumbuhan bobot dibandingkan panjang. Sintasan yang diperoleh selama penelitian pada masing-masing perlakuan sebesar $100 \%$ hal ini menunjukkan tingkat sintasan dan toleransi yang baik biota uji terhadap perlakuan kombinasi intensitas cahaya dan warna latar.

\section{Warna Badan Ikan}

Penampakan warna secara visual, ikan yang diberikan perlakuan intensitas cahaya yang lebih tinggi dan latar yang lebih terang akan membuat ikan menjadi lebih pucat (Tabel 3). Ikan hias akan berwarna bagus dan cerah apabila perairan tempat pemeliharaannya dalam kondisi terang dan terkena sinar atau cahaya yang optimal (Said et al., 2005).

Ikan cupang yang mendapatkan cahaya yang optimal akan memunculkan warna yang lebih tegas, hal ini diduga reaksi dari pigmen melanofor akan menghasilkan warna yang lebih baik dalam kondisi cahaya yang sesuai. Dalam kondisi cahaya dan warna latar yang sesuai, maka warna badan ikan akan menjadi cerah (tidak pucat) dengan warna badan yang tegas dan jelas. Warna badan dan sirip akan terlihat semakin menarik, karena warnanya yang lebih muncul. Perubahan cahaya yang kurang stabil membuat ikan lebih stres dan warnanya kurang muncul. Cahaya juga sangat diperlukan untuk pigmentasi, karena hal ini merupakan faktor penting yang memengaruhi perkembangan awal dan pertumbuhan. Cahaya yang terlalu kuat bisa menyebabkan stres atau bahkan mematikan. Beberapa spesies ada yang mampu tumbuh dan berkembang pada intensitas sangat rendah atau dalam kondisi tidak ada cahaya.

Delta (perubahan) nilai hue akhir penelitian yang dihasilkan cenderung menghasilkan perubahan warna dengan nilai positif yang artinya warna menjadi lebih kebiruan, dan apabila nilainya negatif warna akan menjadi lebih kehijauan (Tabel 4). Nilai delta saturasi, apabila diperoleh nilai delta yang positif maka warna akan semakin tegas, dan apabila nilainya deltanya negatif, maka warnanya akan lebih pudar. Sama halnya dengan nilai delta brightness, nilai positif akan semakin terang, dan negatif akan cenderung lebih gelap (Gambar 3). 


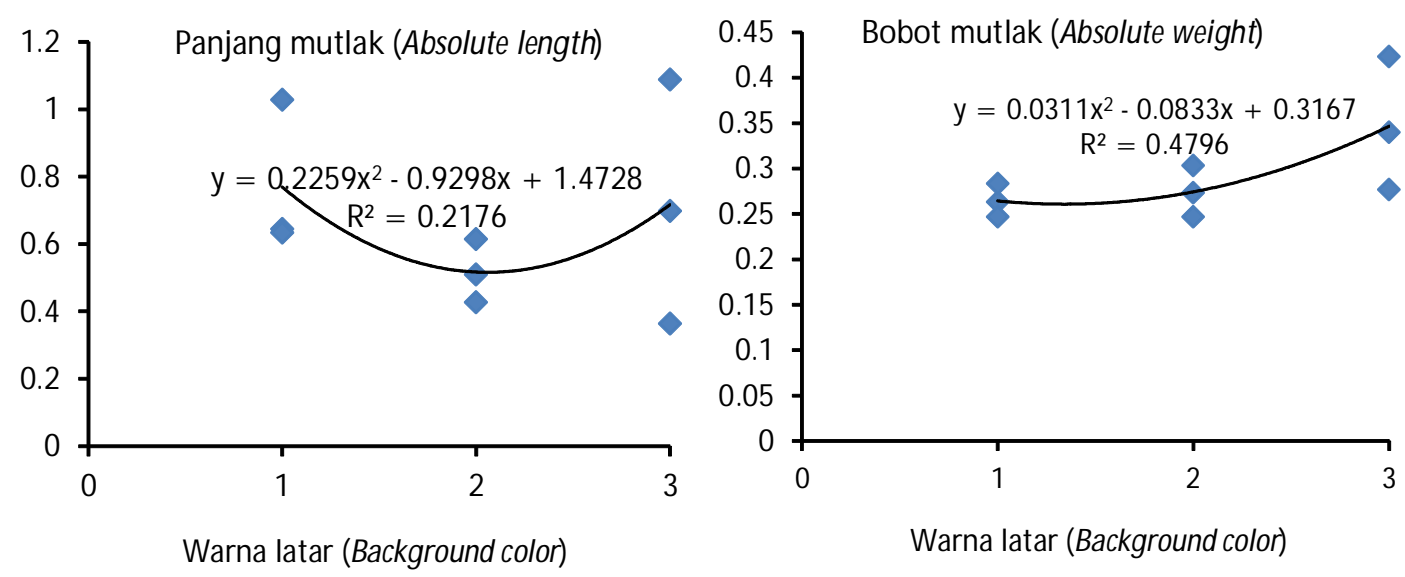

Gambar 2. Korelasi pertumbunan panjang dan bobot mutlak dengan warna latar wadah pemeliharaan

Figure 2. Corelation of length and weight growth with background color of rearing container

Warna latar hitam membuat perubahan warna (pigmentasi) ikan cupang menjadi lebih rendah dibandingkan dengan perlakuan warna latar lainnya (cenderung stabil). Perlakuan perbedaan intensitas cahaya memengaruhi kadar brightness dan saturation, intensitas cahaya yang lebih tinggi (800 lux dan 1.500 lux) menurunkan kualitas warna ikan ditandai dengan nilai delta saturation yang negatif. Pada intensitas cahaya rendah (100 lux) kualitas warna cenderung stabil, nilai delta saturation dan brightness cenderung positif (Gambar 4). Pigmentasi yang cenderung stabil pada perlakuan latar hitam diduga karena pada kondisi tidak terlalu terang, tingkat stres ikan akan lebih rendah. Pada saat ikan stres, warna badan ikan akan cenderung memucat. Nilai delta saturasi semakin tinggi maka warna badan ikan akan semakin terlihat warnanya. Ketegasan warna terlihat lebih tegas pada intensitas cahaya yang lebih rendah (intensitas 100 lux). Kadar brightness yang semakin tinggi akan membuat warna ikan menjadi lebih pucat. Perlakuan kombinasi intensitas cahaya 100 lux dengan latar putih dan biru memberikan pengaruh kualitas warna ikan yang lebih baik, dilihat dari nilai delta hue dan saturation-nya yang positif, serta delta brightness yang tidak terlalu tinggi.

Tabel 3. Perubahan warna ikan uji sebelum dan setelah perlakuan

Table 3. Color change of experimental fish before and after treatment

\begin{tabular}{|c|c|c|c|}
\hline \multirow{2}{*}{$\begin{array}{l}\text { Perlakuan } \\
\text { Treatments }\end{array}$} & \multicolumn{3}{|c|}{ Intensitas (Intensity) (lux ) } \\
\hline & 100 & 800 & 1,500 \\
\hline \multicolumn{4}{|l|}{$\begin{array}{l}\text { Latar putih } \\
\text { White background }\end{array}$} \\
\hline \multicolumn{4}{|l|}{$\begin{array}{l}\text { Latar hitam } \\
\text { Black background }\end{array}$} \\
\hline $\begin{array}{l}\text { Latar biru } \\
\text { Blue background }\end{array}$ & & & \\
\hline
\end{tabular}


Tabel 4. Selisih perubahan warna ikan uji selama penelitian dalam nilai HSB Table 4. Change difference of sample fish colour during experiment on HSB value

\begin{tabular}{|c|c|c|c|c|c|c|c|c|c|}
\hline \multirow{3}{*}{$\begin{array}{l}\text { Perlakuan } \\
\text { (Treatments ) }\end{array}$} & \multicolumn{6}{|c|}{$\begin{array}{l}\text { Pengukuran } \\
\text { (Measurement) }\end{array}$} & \multicolumn{3}{|c|}{$\begin{array}{c}\Delta \text { akhir (perubahan } \\
\text { warna) }\end{array}$} \\
\hline & \multicolumn{3}{|c|}{ Awal (Initial) } & \multicolumn{3}{|c|}{ Akhir (Final) } & \multirow[b]{2}{*}{ H } & \multirow[b]{2}{*}{$\mathbf{S}$} & \multirow[b]{2}{*}{ B } \\
\hline & H & $\mathbf{S}$ & B & H & $\mathbf{S}$ & B & & & \\
\hline A-1 & 179 & 28 & 84 & 200 & 34 & 90 & 21 & 6 & 6 \\
\hline$A-2$ & 179 & 20 & 79 & 194 & 41 & 95 & 16 & 22 & 16 \\
\hline$A-3$ & 183 & 26 & 75 & 195 & 39 & 80 & 12 & 13 & 5 \\
\hline B-1 & 186 & 47 & 76 & 200 & 33 & 97 & 14 & -14 & 21 \\
\hline B-2 & 199 & 45 & 79 & 205 & 22 & 91 & 6 & -23 & 11 \\
\hline B-3 & 176 & 39 & 83 & 203 & 35 & 92 & 26 & -4 & 10 \\
\hline C-1 & 183 & 42 & 82 & 205 & 37 & 87 & 22 & -5 & 5 \\
\hline$C-2$ & 194 & 38 & 90 & 205 & 45 & 84 & 12 & 7 & -6 \\
\hline$C-3$ & 178 & 38 & 79 & 199 & 31 & 93 & 20 & -7 & 14 \\
\hline
\end{tabular}
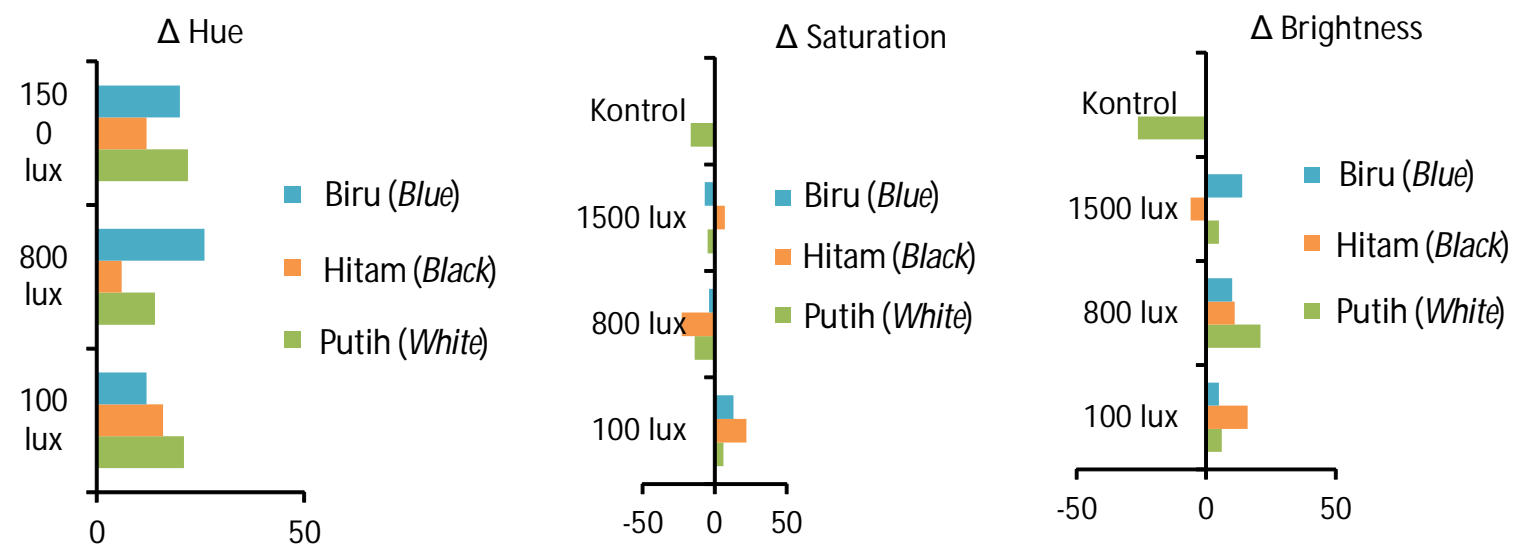

Gambar 3. Perubahan warna ikan uji dalam hue, saturation, dan brightness

Figure 3. Colour change of experimental fish in based on hue, saturation, and brightness

Tabel 5. Kualitas air selama penelitian

Table 5. Water quality during treatment

\begin{tabular}{lccc}
\hline \multirow{2}{*}{ Parameter (Parameters) } & \multicolumn{3}{c}{ Nilai kisaran (Range value) } \\
\cline { 2 - 4 } & $\mathbf{A}$ & $\mathbf{B}$ & $\mathbf{C}$ \\
\hline $\mathrm{pH}$ & $6.5-6.7$ & $6.5-6.6$ & $6.5-6.9$ \\
$\mathrm{DO}(\mathrm{mg} / \mathrm{L})$ & $3.35-5.85$ & $4.01-6.33$ & $4.25-6.66$ \\
$\mathrm{NH}_{3}(\mathrm{mg} / \mathrm{L})$ & $0.0005-0.001$ & $0.0005-0.001$ & $0.0005-0.001$ \\
$\mathrm{CO}_{2}$ (mg/L) & $2-4$ & $3-4$ & $4-6$ \\
$\mathrm{Alkalinitas} / \mathrm{Alkalinity}(\mathrm{mg} / \mathrm{L})_{\mathrm{Hardness}(\mathrm{mg} / \mathrm{L})}^{22.66-33.98}$ & $22.66-33.98$ & $22.66-33.98$ \\
$\mathrm{NO}_{2}$ (mg/L) & $23.10-38.50$ & $29.26-35.42$ & $35.42-63.14$ \\
\hline
\end{tabular}


Beberapa ikan terlihat lebih baik pada latar wadah yang berwarna terang (Tamazouzt et al., 2000), tetapi beberapa ikan terlihat lebih baik dengan latar belakang berwarna gelap (Naas et al., 1996; Martin-Robichaud \& Peterson, 1998; Lin et al., 2009). Lebih lanjut menurut Mairesse et al. (2005); Strand et al. (2007), menyatakan bahwa perbedaan yang jelas pada warna badan ikan perch terlihat dalam wadah pemeliharaan hitam dan putih. Ikan perch yang dipelihara pada tangki hitam terlihat berwarna lebih hitam, dan akan terlihat berwarna lebih pucat jika dipelihara dalam tangki putih.

\section{Kualitas Air}

Kisaran kualitas air yang meliputi $\mathrm{pH}, \mathrm{DO}$, amonia $\left(\mathrm{NH}_{3}\right), \mathrm{CO}_{2}$, alkalinitas, hardness, dan nitrit $\left(\mathrm{NO}_{2}\right)$ masih mendukung kehidupan ikan cupang alam (Betta sp.) selama pemeliharaan. Menurut Alabaster \& Lloyd (1982), bahwa oksigen terlarut yang baik untuk kehidupan ikan secara normal adalah 3,0 mg/L. Menurut Spotte (1979), kadar nitrit yang membahayakan kehidupan organisme air adalah di atas $1,0 \mathrm{mg} / \mathrm{L}$.

\section{KESIMPULAN}

Ikan cupang yang dipelihara pada kondisi cahaya dan warna latar yang tidak optimal membuat warna ikan cenderung lebih pucat dan stres, sehingga memperlambat pertumbuhannya. Pertumbuhan dan kualitas warna ikan cupang (Betta sp.) terlihat lebih baik pada kondisi pemeliharaan intensitas cahaya rendah (100 lux) dan warna latar putih.

\section{UCAPAN TERIMA KASIH}

Terima kasih juga disampaikan kepada Saudara Asep Solihin dan Utay sebagai teknisi pada hatcheri cupang alam yang telah membantu persiapan dan pelaksanaan penelitian ini.

\section{DAFTAR ACUAN}

Alabaster, J.S., \& Lloyd, R. (1982). Water quality criteria for freshwater. Second ed. FAO-United Nation. Butterworth, $361 \mathrm{hlm}$.

Anonym. (2013). Penggunaan warna. Modul pelatihan Multimedia. Tanggal 28 Agustus-9 September 2006. http://www.fali.unsri.ac.id. Diakses: 8 Oktober 2013.

Colihueque, N. (2010). Genetics of salmonid skin pigmentation: clues and prospects for improving the external appearance of farmed salmonids. Rev. Fish Biol. Fisheries, 20, 71-86.

Corazani, D. (1997). Crecimiento y consumo de alimento en abalones juveniles Haliotis discus hannai. Ino, 1953, y Haliotis rufescens Swainson,
1822, alimentados con diferentes dietas. Memoria de Ingeniero en acuacultura. Departamento de Acuacultura. Facultad de Ciencias del Mar. Universidad Cato ' lica del Norte, $57 \mathrm{pp}$.

Daniels, H.V., Berlinsky, D.L., Hodson, R.G., \& Sullivan, C.V. (1996). Effects of stocking density, salinity, and light intensity on growth and survival of Southern flounder Paralichthys lethostigma larvae. J. World Aquacult. Soc., 27, 153-159.

Goldstein, R.J. (2004). The Betta handbook. Barron's Educational Series, Inc. New York.

Han, D., Xie, S., Zhu, X., \& Yang, Y. (2005). Effect of light intensity on growth, survival and skin color of juvenile Chinese longsnout catfish (Leiocassis longirostris). Aquaculture, 248, 299-306.

Henne, J.P., \& Watanabe, W.O. (2003). Effect of light intensity, salinity on growth, survival and whole body osmolarity of larval. Southern flounder Paralichtys letostigma. Journal world Aquaculture Sacrifice, 34, 450-465.

Hole, G., \& Pittman, K. (1995). Effects of light and temperature on growth in juvenile halibut Hippoglossus. hippoglossus L. In Pittman, K., Batty, R.S., \& Verreth, J. (Eds.). ICES Marine Science Symposia, Mass Rearing of Juvenile Fish. Bergen, 2123 June 1993; 201, 197.

Jentoft, S., Oxnevad, S., Aastveit, A.H., \& Andersen, O. (2006). Effects of tank wall color and up-welling water flow on growth and survival of Eurasian perch larvae (Perca fluviatilis). J. World Aquac. Soc., 37, 313-317.

Lin, Q., Lin, J., \& Huang, L. (2009). Effects of substrate color, light intensity and temperature on survival and skin color change of juvenile seahorses, Hippocampus erectus Perry, 1810. Aquaculture, 298(1-2), 157-161.

Mairesse, G., Thomas, M., Gardeur, J.-N., \& Brun-Bellut, J. (2005). Appearance and technological characteristics in wild and reared Eurasian perch, Perca fluviatilis (L.). Aquaculture, 246, 295-311.

Martin-Robichaud, D.J., \& Peterson, R.H. (1998). Effects of light intensity, tank colour and photoperiod on swimbladder inflation success in larval striped bass, Morone saxatilis (Walbaum). Aquac. Res., 29, 539-547.

Mills, E.L., Confer, J.L., \& Kretchmer, D.W. (1986). Zooplankton selection by young yellow perch: the influence of light, prey density, and predator size. Trans. Am. Fish. Soc., 115, 716- 725.

Naas, K., Huse, I., \& Iglesias, J. (1996). Illumination in first feeding tanks for marine fish larvae. Aquat. Eng., 15, 291-300. 
Said, D.S., \& Tanjung, L.R. (1997). Pengaruh suhu dan fotoperiode pada pemijahan ikan pelangi (Melanotaenia boesemani) perilaku pada musim hujan. Limnotek, 5(1), 31-38.

Said, D.S., Supyawati, I.W.D., \& Noortiningsih. (2005). Pengaruh jenis pakan dan kondisi cahaya terhadap penampilan warna ikan pelangi merah Glossolepis incisus jantan. Jurnal Iktiologi Indonesia, 5(2), 7.

Spotte, S. (1979). Fish and invertebrate culture. Waler Management in Closed System, Second Ed. John Wiley \& Sons. New York, 17 pp.

Strand, A., Alanärä, A., Staffan, F., \& Magnhagen, C. (2007). Effects of tank colour and light intensity on feed intake, growth rate and energy expenditure of juvenile Eurasian perch, Perca fluviatilis $L$. Aquaculture, 272, 312-318.

Tamazouzt, L., Béatrice, C., \& Pascal, F. (2000). Tank wall colour and light level affect growth and survival of Eurasian perch larvae (Perca fluviatilis L.). Aquaculture, 182, 85-90.
Tan, H.H. (2011). Diversity of Fighting Fishes - Ikan Cupang. Makalah dipresentasikan pada Forum Inovasi Teknologi Akuakultur, Bali 2011. Pusat Penelitian dan Pengembangan Perikanan Budidaya, $37 \mathrm{hlm}$.

Tume, R.K., Sikes, A.L., Tabrett, S., \& Smith, D.M. (2009). Effect of background colour on the distribution of astaxanthin in black tiger prawn (Penaeus monodon): Effective method for improvement of cooked colour. Aquaculture, 296, 129-135.

Van der Salm, A.L., Martinez, M., Flik, G., \& Wendelaar Bonga, W.E. (2004). Effects of husbandry conditions on the skin colour and stress response of red porgy, Pagrus pagrus. Aquaculture, 241, 371386.

Wardley, T. (2001). Pot-bellied seahorses and their colours. Masters Thesis. University of Tasmania. Australia, $98 \mathrm{pp}$.

Woods. (2000). Improving initial survival in cultured seahorses, Hippocampus abdominalis Leeson, 1827 (Teleostei: Syngnathidae). Aquaculture, 190, 377388. 